\title{
Trends of Immuno-virological Response Among HIV- Infected Patients Receiving Highly Active Anti-retroviral Therapy at Hawassa, Southern Ethiopia
}

\author{
Agete Tadewos Hirigo ${ }^{1}$, *, Demissie Assegu Fenta ${ }^{1}$, Tedewos Beyene Bala ${ }^{2}$, Selamawit Gutema Bule ${ }^{2}$, \\ Meseret Regassa Gemechu ${ }^{2}$
}

${ }^{1}$ College of Medicine and Health Science department of Medical Laboratory Science, Hawassa University, Hawassa, Southern Ethiopia

${ }^{2}$ College of Medicine and Health Science Teaching Hospital, Hawassa University, Hawassa, Southern Ethiopia

\section{Email address:}

agetetadewos@yahoo.com (A. T. Hirigo), demissieasegu@yahoo.com (D. A. Fenta), tadibala@yahoo.com (T. B. Bala), selamawitg@yahoo.com (S. G. Bule), mesretr@yahoo.com (M. R. Gemechu)

\section{To cite this article:}

Agete Tadewos Hirigo, Demissie Assegu Fenta, Tedewos Beyene Bala, Selamawit Gutema Bule, Meseret Regassa Gemechu. Trends of Immuno-virological Response Among HIV-Infected Patients Receiving Highly Active Anti-retroviral Therapy at Hawassa, Southern Ethiopia. Clinical Medicine Research. Vol. 4, No. 4, 2015, pp. 104-110. doi: 10.11648/j.cmr.20150404.13

\begin{abstract}
Background: Immunological and virological response evaluation is one of a critical tool for assessing treatment outcome, regimen change and patient's management. However, data concerning any change in immunological and virological response in HIV infected patients using anti-retroviral treatment (ART) is scarce in Ethiopia. Method: This retrospective cohort study was conducted from April 2010-September 2013 at ART clinic of Hawassa University referral hospital. A total of 86 HIV-infected patients receiving Tenofovir, Stavudine and Zidovudine based regimen with either of Efavirenz or Nevirapine during ART initiation. Lamivudine is common for all. Adequate immune-virological response for most patients under treatment is defined as an increase in CD4 cells of 50-150/ $\mu$ l per year and viral load (VL) drops to undetectable level ( $<150 \mathrm{copies} / \mathrm{ml})$ after $\geq 6$ months of ART. Statistical analysis was done using Statistical Package for Social Sciences (SPSS) Version 20. Results: mean CD4+ cells count shows significant increment at 6, 12, 18 and 24 months after ART treatment among patients having VL $<5(\log 10)$ compared to those VL $\geq 5(\mathrm{p}=0.04 ; 0.002 ;<0.0001 ; 0.001)$ respectively. Female have insignificantly better Mean CD4+ cells throughout 24 months. Also patients over 50 years of age do show an immune response after ART initiation. But, in relative to younger patients, their CD4 cells recovery is insignificantly sluggish. CD4+ cells and body weight of concordant positive responders show significant rising trend at $6,12,18,24$ months when compared to discordant responders + concordant non-responders $(0.003$ vs. $0.05 ;<0.0001$ vs. $0.04 ; 0.001$ vs. $0.008 ; 0.001$ vs. 0.03$)$ respectively. Moreover logistic regression models were applied and significant factors associated with discordant immuno-virological response were patient's body weight $(A O R=0.14 ; 95 \% \mathrm{CI}: 0.03-0.7 ; \mathrm{p}=0.02)$ and residence $(\mathrm{AOR}=20.3 ; 95 \% \mathrm{CI}: 2.2-188$; $\mathrm{p}=0.008)$. Conclusion: Immunovirological response evaluation is a critical tool for assessing treatment outcome, regimen change and patient's management and the response trend decision should include both CD4+ cells and viral load results concurrently.
\end{abstract}

Keywords: Immuno-virological Response, ART, HIV, Hawassa, Ethiopia

\section{Introduction}

Even though, the absence of curative therapy for Human Immunodeficiency Virus (HIV) /acquired immunodeficiency syndrome (AIDS), the introduction of antiretroviral therapy (ART) has seen a decline in the morbidity and mortality associated with HIV infection in the worldwide $[1,2]$. This is a consequence of the ability of ART to suppress HIV viraemia to undetectable levels and allow immune restoration, resulting in an increase in circulating CD4 cells [3]. Current antiretroviral therapy (ART) is highly effective in dropping the viral load of the HIV to undetectable levels and providing a consistent increase in the number of CD4+ $\mathrm{T}$ lymphocytes $[4,5]$. Patient responses and clinical diagnostic measures to ART show differences based on individual, population 
characteristics and the type of setting where treatment is delivered [6]. The immunological response in a successful ART is judged by an increase in CD4 cells of 150-200/ $\mu$ in the first year and then more progressively [7]. An adequate immunological response for most patients under treatment is defined as an increase in CD4 cells of $50-150 / \mu 1$ per year, generally with quicker response during the first 3 months [8]. Whereas appropriate adherence to ART, is expected to be the viral load (VL) drops to undetectable level $(<150$ copies $/ \mathrm{ml}$ ) after $\geq 6$ months of ART [9]. In practice, not all ART patients attain the desired concordant response of viral suppression with CD4 cell count increase; but around 20 $40 \%$ of patients do not show a significant increase in CD4 cell count despite viral suppression [10]. Discordant immune response may arise either as a result of failed immune reconstitution or the excessive destruction of CD4 cells and it consequences of developing AIDS and even it may leads to death $[10,11]$.

Immunological and virological response evaluation is one of a critical tool for assessment of treatment outcome, regimen change and patient's management. Therefore, this retrospective cohort study aimed to assess the trends of immunological and virological response among HIVinfected patients receiving ART at Hawassa University Referral Hospital, Southern Ethiopia

\section{Methods}

\subsection{Study Setting and Study Population}

Hawassa University teaching Hospital is a referral hospital and it was established in November, 2005. It serves for more than 10 million people and provides health services for populations of south nations and nationalities regions (SNNPR) and others. In addition this hospital is one of the health facilities which provide ART service for HIV infected patients in the region.

Criteria to include records of eligible cases were age $\geq 18$ years, receiving ART for a minimum of 24 months and have a good ART adherence (adherence rate $\geq 95 \%$ ). In addition records of the eligible cases must have five consecutive CD4+ cells count and three consecutive viral load results starting from baseline of ART commencement. Female patients with history of pregnancy were excluded.

\subsection{Study Design}

This retrospective cohort study was conducted from April 2010 to September 2013 among HIV infected patients using ART at Hawassa University referral hospital, Hawassa, Southern Ethiopia.

\subsection{Data Collection and Assessment}

\subsubsection{Data Collection}

Demographic, clinical, laboratory results and other related data were extracted from each eligible patient card by using a standard format.

\subsubsection{Outcome Assessment}

Immune response was defined as a minimum absolute increase in the CD4 cell count minimum 50 cells/ $\mu 1$ within 6-12 months after ART initiation [8]. Viral suppression was defined as a VL become $<150$ copies/ml or undetectable after $\geq 6$ months of ART initiation [9].

Therefore, depending on clinical practices the immunovirological responders were categorized in to three groups through CD+ cells count and VL level within 6-12 months after ART commencement:-

1. Concordant responders (VL $<150$ copies/ml and CD4+ cells increase $\geq 50 / \mu 1$ )

2. Concordant non-responders (VL $>150$ copies $/ \mathrm{ml} / \mathrm{CD} 4+$ cells increase $<50$ cells $/ \mu \mathrm{l})$

3. Discordant responders which is sub divided as immunological non-responders (VL >150copies/ml and $\mathrm{CD} 4+$ cells increase $\geq 50 / \mu \mathrm{l})$ or $(\mathrm{VL}$ $<150$ copies/ml and CD4+ cells increase $<50$ cells $/ \mu \mathrm{l})$, in comparison with baseline values $[12,13,14]$.

Finally every six month change in CD4+ cells count was calculated for each individual patient as: (concentration [X month after ART initiation] - concentration [A month]). Moreover percentage change was calculated for each individual patient as: ((concentration [X month after ART switch] - concentration [A month]) / concentration [switch baseline]) X100, adopted from van Leth F et al., 2004 [15].

\subsection{Statistical Analysis}

Data entry and Database management was completed using EPI-INFO 2002. Statistical analyses were done using Statistical Package for Social Sciences (SPSS) Version 20. Categorical variables were summarized as frequencies and percentages while mean values and standard errors were tabulated for normally distributed variables. Median values and interquartile range (IQR) were tabulated for skewed variables. Chi-square test and fisher exact test were used for categorical variables while comparison of quantitative variables at the ART initiation to every six month was analyzed with student $t$-test or Mann-Whitney $U$-test for those variables did not follow normal distribution. The alpha level was set at $5 \%$ for significance.

\subsection{Ethical Considerations}

The study was approved by the institutional review board (IRB) of Hawassa University College of Medicine and Health Science.

\section{Results}

\subsection{Socio-demographic and Behavioral Characteristics of the Study Participants}

A total of 86 participants were met the inclusion criteria. The mean age of the study subjects was $33 \pm 10.5$ years (females $31.4 \pm 10.2$ and males $35.6 \pm 10.7$ ); with the minimum and maximum ages were 18 and 60 years. According to WHO definition, first-line HAART regimens 
were combinations of 2 nucleoside reverse transcriptase inhibitors (NRTIs) and 1 non nucleoside reverse transcriptase inhibitors (NNRTIs). NRTIs backbone drugs are Stavudine (d4T), Zidovudine (AZT), Tenofovir (TDF) and lamivudine (3TC); whereas NNRTIs are Efavirenz (EFV) and Nevirapine (NVP). All regimens included lamivudine (3TC). The number of patients on $\mathrm{d} 4 \mathrm{~T} / 3 \mathrm{TC} / \mathrm{EFV}, \quad \mathrm{ZDV} / 3 \mathrm{TC} / \mathrm{EFV}$, and TDF/3TC/EFV regimens were $1(1.1 \%), 7(8.1 \%)$ and $66(76.7 \%)$ respectively; whereas patients on $\mathrm{ZDV} / 3 \mathrm{TC} / \mathrm{NVP}$, and TDF/3TC/NVP were $4(4.7 \%)$ and $8(9.3 \%)$ respectively. Furthermore baseline median CD4+cells count was 160 with the IQR of 107-203 cells/ $\mu$; and Socio-demographic and other characteristics are described in table-1.

Table 1. Characteristics of the study population at Hawassa University referral hospital, Hawassa, southern Ethiopia.

\begin{tabular}{|c|c|c|c|}
\hline Characteristics & № $(\%)$ & Characteristics & № $(\%)$ \\
\hline Sex $=$ female & $54(62.8)$ & $\begin{array}{l}\text { Opportunistic infections } \\
\text { (OIS ) }\end{array}$ & \\
\hline Male & $32(37.2)$ & No & $34(39.5)$ \\
\hline Age in years & & Tuberculosis & $21(24.4)$ \\
\hline$\leq 20$ & $12(14.0)$ & Herpes zoster & $10(11.6)$ \\
\hline $21-30$ & $35(40.7)$ & Oral Candidasis & $5(5.8)$ \\
\hline $31-40$ & $22(25.6)$ & Herpes simplex & $2(2.3)$ \\
\hline $41-50$ & $10(11.6)$ & Pneumonia and others & $14(16.3)$ \\
\hline$>50$ & $7(8.1)$ & $\begin{array}{l}\text { Risk factors HIV } \\
\text { infections }\end{array}$ & \\
\hline Educational status & & No & $70(81.4)$ \\
\hline Illiterate & $15(17.4)$ & Casual partners & $10(11.6)$ \\
\hline Primary & $34(39.5)$ & Soft/hard drugs & $2(2.3)$ \\
\hline Secondary & $29(33.7)$ & Alcohol + khat chewing & $2(2.3)$ \\
\hline Tertiary & $8(9.3)$ & Tobacco + alcohol & $2(2.3)$ \\
\hline Marital status & & Condom use & \\
\hline Single & $16(18.6)$ & Never use & $66(76.7)$ \\
\hline Married & $50(58.1)$ & Rarely & $19(22.1)$ \\
\hline Separated & $3(3.5)$ & Always & $1(1.2)$ \\
\hline Widow/widower & $12(14.0)$ & $\begin{array}{l}\text { Baseline CD4+ count in } \\
\text { cells } / \mu 1\end{array}$ & $156(71.1)$ \\
\hline Divorced & $5(5.8)$ & $<100$ cells $/ \mu \mathrm{L}$ & $19(22.1)$ \\
\hline WHO clinical stage & & $100-200$ cells $/ \mu \mathrm{L}$ & $45(52.3)$ \\
\hline I & $9(10.5)$ & $>200$ cells $/ \mu \mathrm{L}$ & $22(25.6)$ \\
\hline II & $30(34.9)$ & $\begin{array}{l}\text { Baseline Viral load, } \\
\log _{10} \text { mean }(\mathrm{SD})\end{array}$ & $5.3(0.75)$ \\
\hline III & $40(46.5)$ & $<5$ & $29(33.7)$ \\
\hline IV & $7(8.1)$ & $\geq 5$ & $57(66.3)$ \\
\hline \multicolumn{4}{|l|}{ Residence } \\
\hline Rural & $21(24.4)$ & & \\
\hline Urban & $65(75.6)$ & & \\
\hline
\end{tabular}

WHO, world health organization; SD, standard deviation; HIV, human immunodeficiency virus

\subsection{CD4+cells Count in Relation to Baseline Viral Load Level}

The mean CD4+ cells of month-6, 12, 18 and 24 were significantly higher in $\mathrm{VL}<5 \log$ group when compared with $\mathrm{VL} \geq 5 \log$ group; $\mathrm{p}$ value: $0.04,0.002,<0.0001$ and 0.001 respectively. Also change in month -12 and 24 were significantly higher in patients with $\mathrm{VL}<5 \log$ group (table-2). More over there were no significant deference in females vs. males regarding mean VL $\left(\log _{10}\right)$ during baseline ART of treatment (5.2 vs. $5.5 ; \mathrm{p}=0.07)$ respectively and patients with age $\geq 50$ had insignificantly higher viral load compared to age $<50$ (5.4 vs.5.3; $\mathrm{p}=0.83)$ respectively.

Table 2. Comparison of CD4+ cells in relation with baseline viral load level at Hawassa University referral hospital, Hawassa, southern Ethiopia.

\begin{tabular}{|c|c|c|c|}
\hline \multirow[b]{2}{*}{ Variable } & \multicolumn{2}{|c|}{$\begin{array}{l}\text { Based on baseline viral } \\
\text { load level }\left(\log _{10}\right)\end{array}$} & \multirow[b]{2}{*}{ P value } \\
\hline & $\mathbf{V L} *<\mathbf{5}$ & $V L * \geq 5$ & \\
\hline \multicolumn{4}{|l|}{ CD4+count in cells $/ \mu 1$ (mean, SE) } \\
\hline CD4+cells ( 0 month) & $172(10.3)$ & $149(10.2)$ & 0.16 \\
\hline CD4+cells (6 month) & $309(27)$ & $249(14.4)$ & 0.04 \\
\hline CD4+cells (12 month) & $357(26.3)$ & $260(17.1)$ & 0.002 \\
\hline CD4+cells (18 month) & $417(25)$ & 299(18.9) & $\begin{array}{l}<0.000 \\
1\end{array}$ \\
\hline CD4+cells (24 month) & $452(28)$ & $319(22.6)$ & 0.001 \\
\hline Change in CD4+cells at 6 month & $136(25.7)$ & $100(13.8)$ & 0.17 \\
\hline Change in CD4+cells at 12 month & $185(24.1)$ & $111(16.3)$ & 0.01 \\
\hline Change in CD4+cells at 18 month & $59.9(14.3)$ & $38.2(12.3$ & 0.28 \\
\hline Change in CD4+cells at 24 month & $279.8(28.6)$ & $170(22.9)$ & 0.005 \\
\hline $\begin{array}{l}\text { Percent change in CD4+count at } 6 \\
\text { month }\end{array}$ & $98.1(22)$ & $1.3(25.4)$ & 0.44 \\
\hline $\begin{array}{l}\text { Percent change in CD4+count at } \\
12 \text { month }\end{array}$ & $26.7(10)$ & $43.3(5.7)$ & 0.13 \\
\hline $\begin{array}{l}\text { Percent change in CD } 4+\text { count at } \\
18 \text { month }\end{array}$ & $23.8(6.1)$ & $9.4(4.7)$ & 0.53 \\
\hline $\begin{array}{l}\text { Percent change in CD } 4+\text { count at } \\
24 \text { month }\end{array}$ & $33.3(10.2)$ & $7.7(3.7)$ & 0.77 \\
\hline
\end{tabular}

SE, standard errors; VL, viral load

\subsection{Trends of 24 Months CD4+ Cells Count}

CD4+ cells count was higher among females when compared with males but not significant. The CD4+ count was insignificantly higher among patients with age of $\leq 50$ years old except CD4+ count of baseline.

Also patients with oral candidasis and Herpes zoster infection have insignificantly higher mean CD4+ cells at $\geq 6$ months of ART treatment when compared non-infected cases. Conversely TB-non infected patients and patients using NVP based regimens have higher CD4+cells count (table-3). 
Table 3. Trends of CD4+ cells count in some independent variables at Hawassa University referral hospital, Hawassa, southern Ethiopia.

\begin{tabular}{|c|c|c|c|c|c|c|c|c|c|}
\hline \multirow[b]{2}{*}{ Variable } & \multicolumn{4}{|c|}{ CD4+ cells (Mean, $\mathrm{SE})$} & \multicolumn{5}{|c|}{ CD4+ count, \% change (Mean, SE) } \\
\hline & $\begin{array}{l}\text { Month 0 } \\
\text { (Baseline) }\end{array}$ & Month6 & Month 12 & Month 18 & Month $24^{\text {th }}$ & Month 6 & Month 12 & Month 18 & Month 24 \\
\hline Sex $=$ Female & $164(8.5)$ & 275(17) & 306(19) & $357(19)$ & $382(23.5)$ & $1.0(21.4)$ & $16(6.4)$ & $32.8(9.7)$ & $5.9(3.5)$ \\
\hline Male & 144(82) & $259(21)$ & $271(25.7)$ & $308(28)$ & $334(31.4)$ & $1.4(33.7)$ & $12.7(8)$ & $25.5(9.8)$ & $12(5.1)$ \\
\hline$P$ value & 0.20 & 0.55 & 0.26 & 0.14 & 0.22 & 0.34 & 0.76 & 0.62 & 0.30 \\
\hline Age $\leq 50$ year & $155(8)$ & $274(14.8)$ & $298(16.8)$ & $342(18)$ & $371(21)$ & $1.2(20.4)$ & $15(5.6)$ & $31(7.9)$ & $9.5(3.1)$ \\
\hline$>50$ year & $169(24)$ & $235(24.6)$ & $255(24.6)$ & $312(42)$ & $313(42.5)$ & $67.3(26)$ & $13.5(10)$ & $23(8.4)$ & $-1.1(7)$ \\
\hline $\mathrm{P}$ value & 0.55 & 0.36 & 0.37 & 0.55 & 0.33 & 0.32 & 0.93 & 0.71 & 0.24 \\
\hline $\mathrm{TB}=\mathrm{No}$ & $162(8.4)$ & 281(16) & $298(17.4)$ & $344(19)$ & $373(22)$ & $1.0(17.9)$ & $13.2(5)$ & $24(5.9)$ & $8.7(3.5)$ \\
\hline Yes & $140(17)$ & $232(21)$ & $277(31)$ & $322(31)$ & $336(35)$ & $1.6(51)$ & $19.7(14)$ & $48(22.3)$ & $6.8(4.8)$ \\
\hline$P$ value & 0.23 & 0.11 & 0.56 & 0.55 & 0.41 & 0.23 & 0.59 & 0.14 & 0.78 \\
\hline $\mathrm{HZ}=\mathrm{No}$ & $157(8.4)$ & $266(14.4)$ & $290(16.3)$ & $331(17)$ & $359(20)$ & $1.2(20.5)$ & $16(5.7)$ & $68(7.8)$ & $9.2(3.1)$ \\
\hline Yes & 153(18) & $297(36)$ & $314(41)$ & $393(44)$ & $402(56.3)$ & $1.1(26.3)$ & $4.8(6.4)$ & $43.9(14)$ & $1.0(8.9)$ \\
\hline$P$ value & 0.88 & 0.45 & 0.62 & 0.22 & 0.47 & 0.83 & 0.48 & 0.84 & 0.36 \\
\hline Candida $=$ No & $157(7.8)$ & $267(12.4)$ & $289(14.6)$ & $336(16)$ & $363(18.6)$ & $1.1(18)$ & $12.9(5.1)$ & $29.7(7.3)$ & $8.8(3)$ \\
\hline Yes & 149(44) & $308(124)$ & $353(117)$ & $370(112)$ & $372(133)$ & $1.2(90)$ & $45.2(27)$ & $37.7(30)$ & $-0.8(14)$ \\
\hline$P$ value & 0.80 & 0.48 & 0.33 & 0.63 & 0.91 & 0.99 & 0.14 & 0.79 & 0.44 \\
\hline NNRTI=EFV & $150(8.1)$ & $260(14.4)$ & $282(16)$ & $334(18)$ & $366(21)$ & $1.2(21)$ & $14.4(4.9)$ & $32.9(7.9)$ & $10(3.2)$ \\
\hline NVP & 193(21) & $327(34.8)$ & $357(43.4)$ & $368(34)$ & $352(43.9)$ & $84.6(21)$ & $17(20.9)$ & $13(10.9)$ & $-5(5.4)$ \\
\hline$P$ value & 0.05 & 0.08 & 0.09 & 0.47 & 0.80 & 0.47 & 0.86 & 0.34 & 0.05 \\
\hline
\end{tabular}

TB, tuberculosis; HZ, Herpes zoster; NNRTI, non-nucleoside reverse transcriptase inhibitors; EFV, Efavirenz ; NVP, Nevirapine; SE, standard errors

\subsection{Trends of Immuno-Virological Responses of Patients}

Concordant positive responders were $60.5 \%$ at 6 months of treatment and this value was increased to $62.8 \%$ at 12 month and concordant negative responders were decreased from $9.3 \%$ to $8.1 \%$. Also discordant responders' proportion reduced from 6 to 12 months $(30.2 \%$ to $29.0 \%)$ respectively and among this proportion, patients with CD4-VL+ decreased from $20.9 \%$ to $13.9 \%$ ). In contrast patients with CD4+VL- were increased from $9.3 \%$ to $13.9 \%$ (figure-1).

Furthermore trends of mean CD4+ cells and body weight of the participants in between concordant positive responders vs. discordant responders + concordant negative responders: in both parameters concordant responders have significantly higher CD4+ cells and body weight except the baseline of HAART commencement (figure-2).

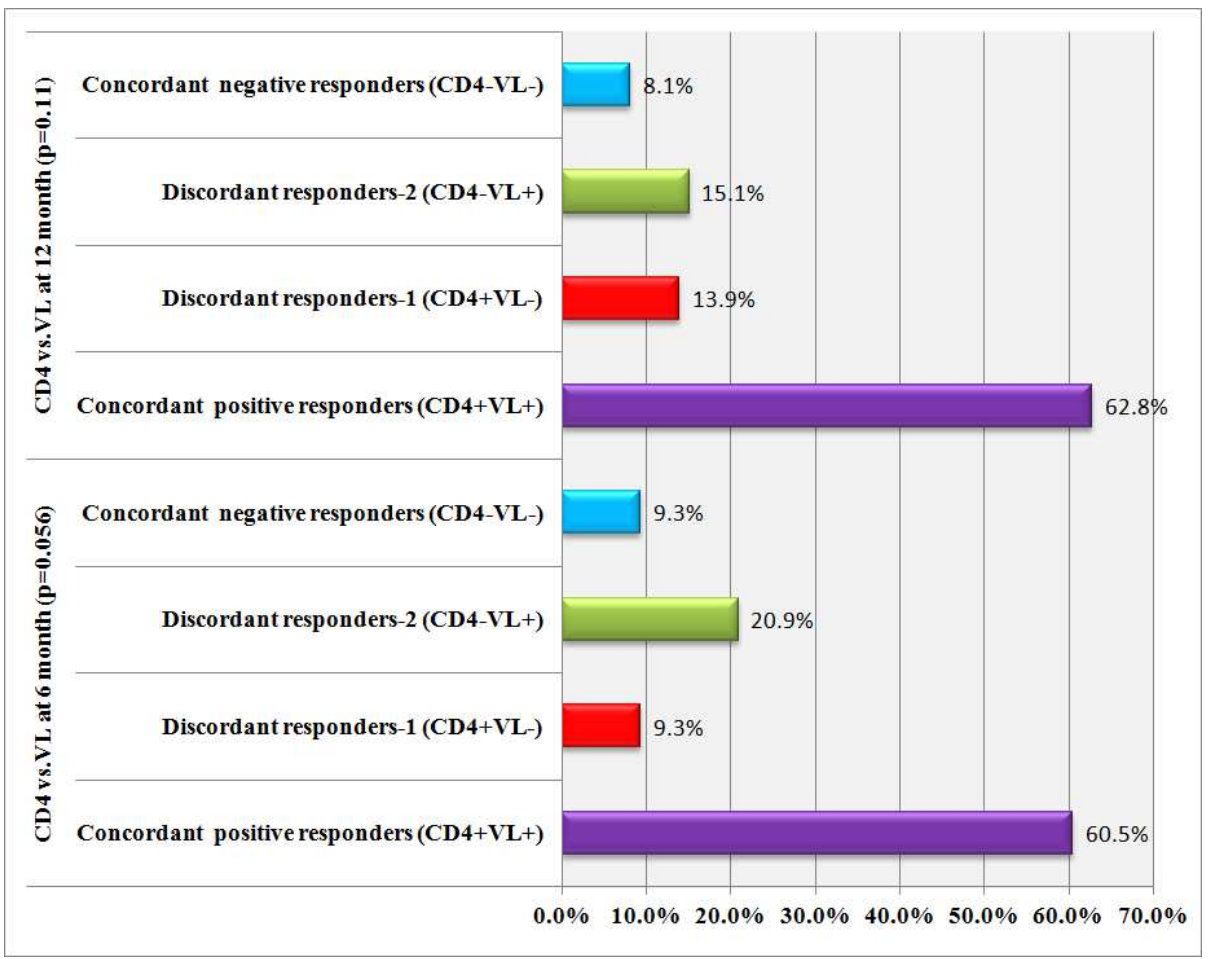

Figure 1. Characteristics of immunological and virological response from 6-12 months after ART at Hawassa University referral hospital, Hawassa, southern Ethiopia. 


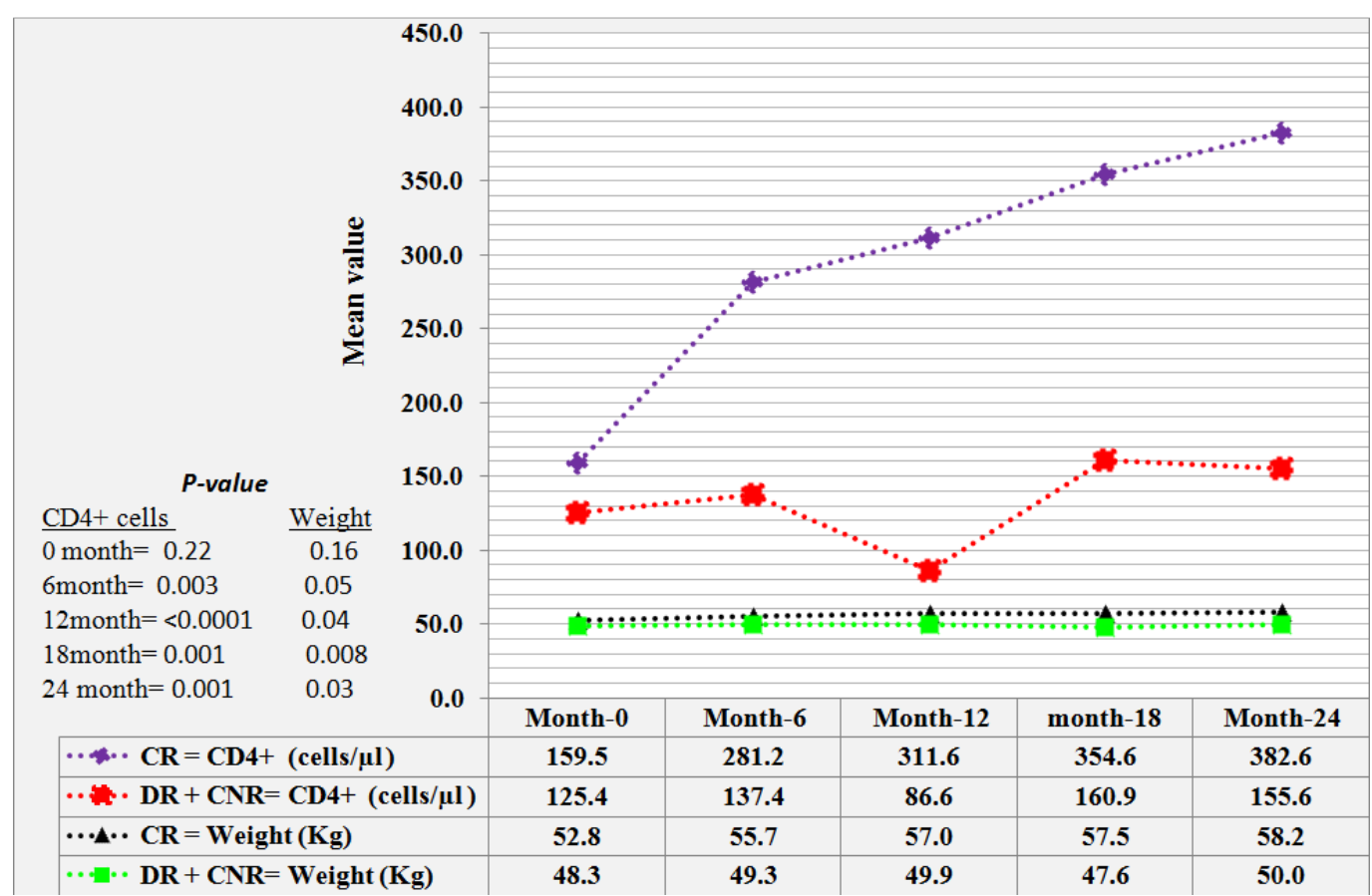

$\mathrm{CR}$, concordant positive responders; $\mathrm{DR}+\mathrm{CNR}$, discordant responders + concordant negative responders

Figure 2. Comparison of CD4+ cells count and body weight in relation with immunological and virological response at Hawassa University referral hospital, Hawassa, southern Ethiopia.

\subsection{Factors Associated with Immuno-Virological Discordant Responders}

Univariate analysis was applied to assess the association of independent factors at 12 months of ART treatment: being living in rural (crude odds ratio $=3.6 ; 95 \%$ CI: $1.0-13.8$ ), and being body weight $<50 \mathrm{~kg}$ (crude odds ratio $=0.39 ; 95 \%$ CI: $0.14-1.0)$ were found to be boarder $(\mathrm{p}=0.05)$ with immunevirological discordant responders. However, on the multivariate analysis the association was adjusted for being living in rural (adjusted odds ratio $=20.3 ; 95 \%$ CI: 2.2- 188), being body weight $<50 \mathrm{~kg}$ (adjusted odds ratio $=0.14 ; 95 \%$ CI: 0.03-0.7) were significantly associated risk factors of immuno-virological discordant responders (table-4).

Table 4. Factors associated with immuno-virological discordant responders at Hawassa University referral hospital, Hawassa, southern Ethiopia.

\begin{tabular}{lllll}
\hline $\begin{array}{l}\text { Explanator } \\
\text { y Variable }\end{array}$ & $\begin{array}{l}\text { Unadjusted } \\
\text { OR (95\% CI) }\end{array}$ & P value & $\begin{array}{l}\text { Adjusted } \\
\text { OR(95\% CI) }\end{array}$ & P value \\
\hline $\begin{array}{l}\text { Residence } \\
\text { Urban }\end{array}$ & 1.00 & & & \\
Rural & $3.6(1.0-13.8)$ & 0.05 & $20.3(2.2-188)$ & 0.008 \\
$\begin{array}{l}\text { Body weight } \\
\text { (Kg) }\end{array}$ & & & & \\
$\geq 50$ & 1.00 & & 1.00 & \\
$<50$ & $0.39(0.14-1.0)$ & 0.05 & $0.14(0.03-0.7)$ & 0.02 \\
\hline
\end{tabular}

*NB: sex; age; Tuberculosis infection; ART drugs; opportunistic infections; educational status; marital status; WHO clinical stages were included during logistic regression analysis and only significant were displayed on the table

\section{Discussion}

The study shows that mean CD4+ T-cell count increments after ART initiation are higher in age $<50$ years in all stage except ART initiation and also the difference is insignificant when comparing these two age groups. In similar with this finding, a study from Brazil reported that changes in CD4+ counts after HAART initiation were not significantly different in patients $\geq 50$ years compared to younger patients [16]. However in contrast to present study a cohort study from 9 African countries, also reports the median increase in CD4+ count was significantly higher at 6 and 12 months after receiving ART in patients younger than 50 years; $\mathrm{P}<$ 0.001 for both phases [17]. The slower CD4+ cell reconstitution in older patients may be related to an impaired thymic function [18] and CD4 reconstitution has been shown to be age dependent $[19,20]$. In addition this study showed that $54.6 \%$ of ART patients were under the category of clinical stage equal to or above III according to WHO criteria; however this rate was lower than the study reported from Bahir Dar, northern part of Ethiopia, which was 69.7\% [21]. The rates of clinical stage start to decline after using ART treatment and taking prophylaxis at baseline [22].

We found that females have higher mean $\mathrm{CD} 4+$ cells from baseline to 24 months when compared to males. Data on gender differences in trends of $\mathrm{CD} 4$ count after commencement of HAART are inconsistent. In line with the other studies report [23, 24] we found no significant differences in $\mathrm{CD} 4+$ reconstitution regarding gender. But other reports indicated that females have better immunological reconstitution compared to males $[25,26,27$, 28]. More over our study indicates lower viral load in female when compared to males at the baseline of ART commencement. This in line with several studies [13, 24, 29, 30]. 
Despite of $62.8 \%$ of concordant positives responders (CD4+VL+), 29\% of patients did not achieve an adequate immune response (discordant) and also $8.1 \%$ concordant negative responders after 12 month of ART initiation in our study. In addition body weight $<50 \mathrm{Kg}$ and living in rural are significantly associated factors for discordant response in our study. However other studies revealed that sex, BMI and ART are identified risk factors for discordant response [31, 32].

\section{Conclusion}

In summary, CD4+ cells count shows significant increment after 6 month of ART treatment among patients having VL $<5 \quad\left(\log _{10}\right)$ compared to those VL $\geq 5$. Female have insignificantly better Mean CD4+ cells from baseline to 24 months of treatment. Also patients over 50 years of age do show an immune response after ART initiation. But, in relative to younger patients, their CD4 cells recovery is insignificantly sluggish. CD4+ cells and body weight of concordant positive responders show significant rising trend after six month of treatment when compared to discordant responders + concordant non-responders. In addition significant factors associated with discordant immunovirological response were patient's body weight and residence.

Therefore immuno-virological response evaluation is a critical tool for assessing treatment outcome, regimen change and patient's management and the response trend decision should be done by using both CD4+ cells and viral load concurrently.

\section{Limitations}

Even though the sample size was relatively small, it was likely to be representative of patients in routine clinical care in the study area. The strength of the results may have been limited by the proportion of missing data. The outcomes were measured between 6 to 24 months after ART initiation; it is therefore probably that factors associated with discordant immune response may have varied with longer periods of treatment.

\section{Authors' Contributions}

A. Tadewos generated and designed the study, performed analysis and interpretation of data including with manuscript drafting and D. Assegu assisted in data entry and critical review. T. Beyene, S. Gutema and M. Regassa assisted in data collection.

\section{Acknowledgements}

We want to acknowledge Hawassa University referral Hospital and our appreciation is also extended to the ART clinic staffs for their immeasurable support during data collection.

\section{References}

[1] Palella FJ, Delaney KM, Moorman AC. Declining morbidity and mortality among patients with advanced human immunodeficiency virus infection. N Engl J Med 1998; 338(13): 853-860.

[2] WHO. Towards universal access: scaling up priority HIV/AIDS interventions in the health sector: progress report 2009.Availablefrom:URL:http://data.unaids.org/pub/Report/ 2009/20090930_tuapr_2009_en.pdf) accessed on 05 April 2015.

[3] Moore DM, Hogg RS, Yip B, Wood E, Tyndall M, Braitstein P, Montaner JS. Discordant immunologic and virologic responses to highly active antiretroviral therapy are associated with increased mortality and poor adherence to therapy. J Acquir Immune Defic Syndr 2005; 40(3):288-293.

[4] Life expectancy of individuals on combination antiretroviral therapy in high-income countries: a collaborative analysis of 14 cohort studies. Lancet 2008; 48:293-9.

[5] Teixeira PR, Vitoria MA, Barcarolo J. Antiretroviral treatment in resource-poor settings: the Brazilian experience. AIDS 2004; 18 (Suppl 3): S: 5-7.

[6] Yamashita TE, Phair JP, Muñoz A, Margolick JB, Detels R, et al. Immunologic and virologic response to highly active antiretroviral therapy in the Multicenter AIDS Cohort Study. AIDS 2001; 15(6): 735-746.

[7] Yeni P. report of the expert group on the medical management of people infected with HIV: recommendations. 2008 report. Available from: http://www.sante.gouv.fr/rapport-du-grouped-experts-2008-surla- prise-en-charge-medicale-des-patientsinfectees-par-le-vih-sousla-direction-du-pr-patrick-yeni.html. Accessed February 8, 2015.

[8] Department of Health and Human Services Panel on Antiretroviral Guidelines for Adults and Adolescents. Guidelines for the use of antiretroviral agents in HIV-1infected adults and adolescents. December 1, 2009. Available from:http://scap.org/documents/GuidlinesforAntiretrovialTher apy12-11-09.pdf. Accessed on Feb 10, 2015.

[9] WHO: Antiretroviral Therapy for HIV infection in Adults and Adolescents: Recommendations for a public health approach 2006 revision. HIV/AIDS Programme: Strengthening health services to fight HIV/AIDS. Geneva: World Health Organization; 2006.

[10] Benveniste O, Flahault A, Rollot F, Elbim C, Estaquier $\mathrm{J}$, Pédron $\mathrm{B}$, et al. mechanisms involved in the low-level regeneration of CD4 cells in HIV 1 infected patients receiving highly active antiretroviral therapy who have prolonged undetecable plasma viral loads. J Infect Dis 2005; 191 (10):1670-1679.

[11] Nicastri E, Chiesi A, Angeletti C, Sarmati L, Palmisano L, Geraci A, et al. Clinical outcome after 4 years follow-up of HIV-seropositive subjects with incomplete virologic or immunologic response to HAART. J Med Virol 2005; 76 (2):153-160.

[12] Kranzer K, Houben RMG, Glynn JR, Bekker L-G, Wood R, Lawn SD. Yield of HIV-associated tuberculosis during intensified case finding in resource-limited settings: a systematic review and meta-analysis. Lancet Infect Dis 2010; 10:93-102. 
[13] Jevtovic D, Salemovic D, Ranin J, Pešic'I, Žerjav S, Djurkovic'-Djakovic O. The dissociation between virological and immunological responses with HAART. Biomedicine \& Pharmacotherapy 2005; 59 (8): 446-451.

[14] Taiwo BO, Li X, Palella F, Jacobson LP, Margolick JB, Detels $\mathrm{R}$, et al. Higher Risk of AIDS or death in patients with lower CD4 Cell Counts after virally suppressive HAART. HIV Medicine 2009; 10 (10):657-660.

[15] van Leth F, Phanuphak P, Stroes E, Gazzard B, Cahn P, Raffi F, et al. Nevirapine and efavirenz elicit different changes in lipid profiles in antiretroviral therapy-naïve patients infected with HIV-1. PLoS Med 2004; 1(1):e19.

[16] Torres TS, Cardoso SW, de Souza VL, Marins LM, Oliveira MS, Veloso VG et al. Aging with HIV: An Overview of an Urban Cohort in Rio de Janeiro (Brazil) across Decades of Life. The Brazilian Journal of Infectious Diseases 2013; 17 (3): 324-331.

[17] Greig J, Casas EC, O’Brien DP, Mills EJ, Ford N. Association between Older Age and Adverse Outcomes on Antiretroviral Therapy: A Cohort Analysis of Programme Data from Nine Countries. AIDS 2012; 26 (S-1): S31-S37.

[18] Douek DC, McFarland RD, Keiser PH, Gage EA, Massey JM, Haynes BF, et al. Changes in thymic function with age and during the treatment of HIV infection. Nature 1998; 396 (6712): 690-695.

[19] Florence E, Lundgren J, Dreezen C, Fisher M, Kirk O, Blaxhult A, et al. Factors associated with a reduced CD4 lymphocyte count response to HAART despite full viral suppression in the Euro-SIDA study. HIV Med 2003; 4(3):255-62.

[20] Stuart J, Hamann D, Borleffs J, Roos M, Miedema F, Boucher $\mathrm{F}$, et al. Reconstitution of naive $\mathrm{T}$ cells during antiretroviral treatment of HIV-infected adults is dependent on age. AIDS 2002; 16(17):2263-6.

[21] Belay A, Alamrew Z, Berie Y, Tegegne B, Tiruneh G, Feleke A. Magnitude and correlates of tuberculosis among HIV patients at Felege Hiwot Referral Hospital, Bahir Dar city, northwest Ethiopia. Clinical medicine research 2013; 2(4): 7783.

[22] Misker D, Agidew E, Tilahun M, Mellie H. Time to increase WHO clinical stage of people living with HIV in public health facilities of Arba Minch town, south Ethiopia. Clinical medicine research 2014; 3(5): 119-124.

[23] Moore AL, Kirk O, Johnson AM, Katlama C, Blaxhult A, Dietrich M, et al: Virologic, immunologic, and clinical response to highly active antiretroviral therapy: the gender issue revisited. J Acquir Immune Defic Syndr 2003; 32(4):452-61.

[24] Nicastri E, Angeletti C, Palmisano L, Sarmati L, Chiesi A, Geraci A, et al: Gender differences in clinical progression of HIV-1-infected individuals during long-term highly active antiretroviral therapy. AIDS 2005; 19:577-583.

[25] Collazos J, Asensi V, Carton JA. Sex differences in the clinical, immunological and virological parameters of HIV-infected patients treated with HAART. AIDS 2007; 21(7):835-843.

[26] Zaragoza-Macias E, Cosco D, Nguyen ML, Del RC, Lennox J: Predictors of success with highly active antiretroviral therapy in an antiretroviral-naïve urban population. AIDS Res Hum Retroviruses 2010; 26 (2):133-138.

[27] Barber TJ, Geretti AM, Anderson J, Schwenk A, Phillips AN, Bansi L, et al: Outcomes in the first year after initiation of first-line HAART amongheterosexu al men and women in the UK CHIC Study. Antivir Ther 2011; 16:805-814.

[28] Maskew M, Brennan T, Westreich D, McNamara L, MacPhail P, Fox M. Gender Differences in Mortality and CD4 Count ResponseAmong Virally Suppressed HIV-Positive Patients. Journal of Women's Health, 2013; 22(2):113-20.

[29] Fardet L, Mary-Krause M, Heard I, Partisani M, Costagliola D: Influence of gender and HIV transmission group on initial highly active antiretroviral therapy prescription and treatment response. HIV Med 2006; 7(8):520-529.

[30] Floridia M, Giuliano M, Palmisano L, Vella S: Gender differences in the treatment of HIV infection. Pharmacol Res 2008; 58(3-4):173-82.

[31] Mocroft A, Philips AN, Gatell J, Ledergerber B, Fisher M. Normalisation of CD4 counts in patients with HIV-1 infection and maximum virological suppression who are taking combination antiretroviral therapy: an observational cohort study. Lancet 2007; 370(9585):407-13.

[32] Patterson K, Napravnik S, Eron J, Keruly J, Moore R. Effects of age and sex on immunological and virological responses to initial highly active antiretroviral therapy. HIV Med 2007; 8(6):406-10. 